\title{
GIVING AWAY MONEY: COMPARATIVE COMMENTS ON CLAIMS RESOLUTION FACILITIES
}

\author{
Mark A. Peterson*
}

INTRODUCTION

Claims resolution facilities are created to provide efficient means to distribute money to claimants, primarily by reducing participation in the litigation system. As the other articles in this symposium indicate, existing claims facilities differ in their emphasis of these and other objectives, and have had varying success. It is still too early to assess these facilities definitively; some have not become fully operational, while others have already been reorganized. Nevertheless, their experiences suggest that certain features may make claims facilities more or less successful in achieving their basic objectives. This article considers how the structures and operations of these facilities relate to their relative success.

\section{II}

\section{The Litigation Posture}

Claims resolution facilities adopt different positions regarding their continued participation in litigation. The Asbestos Claims Facility ("ACF") and its successor, the Center for Claims Resolution ("CCR"), were established primarily to participate in litigation. ${ }^{1}$ Both the ACF and CCR were formed so that member, asbestos litigation defendants could pool their efforts in litigation as well as in settlement negotiations. The Manville Personal Injury Settlement Trust and the Dalkon Shield Claimants Trust were created by bankruptcy plans that allow litigation, but both trusts were intended as settlement rather than litigation vehicles. ${ }^{2}$ These two trusts differed markedly, however, in their powers to create disincentives to litigation. Indeed, the Manville Trust's inability to discourage litigation contributed to the financial difficulties that lead to its reorganization. ${ }^{3}$ In

Copyright $(1990$ by Law and Contemporary Problems

* Senior Research Scientist, Institute for Civil Justice, RAND.

1. See Lawrence Fitzpatrick, The Center for Claims Resolution, 53 L \& Contemp Probs 13 (Autumn 1990).

2. See Marianna S. Smith, Resolving Asbestos Claims: The Manville Personal Injury Settlement Trust, 53 L \& Contemp Probs 27 (Autumn 1990); Kenneth R. Feinberg, The Dalkon Shield Claimants Trust, 53 L \& Contemp Probs 79 (Autumn 1990).

3. In re Joint Eastern and Southern Districts Asbestos Litigation, In re Johns-Manville Corporation, 120 BR 648 (E \& SD NY 1990). 
contrast to these four claims facilities, three other claims resolution facilitiesthe Manville Property Damage Settlement Trust, ${ }^{4}$ the Olin DDT Facility, ${ }^{5}$ and the Agent Orange Settlement Fund ${ }^{6}$-do not allow litigation.

Beyond their varying involvement in litigation, claims resolution facilities also differ in how closely their processes for distributing compensation resemble litigation. Figure 1 describes a dimension of similarity to the litigation process.

\section{Figure 1}

Alternative Models of the Distribution Process Defining a

\section{Dimension of Litigiousness}

LITIGATION MODEL

NONLITIGATION MODEL

\author{
Thorough discovery \\ Individualized damage payments \\ Defenses/causation at issue \\ Full compensation if liability \\ Adversarial \\ Full judicial appeals
}

\author{
Limited discovery \\ Payment categories \\ No defense/causation issues \\ May be partial compensation \\ Nonadversarial \\ Limited appeals
}

At one end, the process for determining compensation might be so thorough, individualized, and adversarial as to mimic the litigation process. At the other end, the process might have none of the features of adversarial litigation; for example, it might categorize claims on the basis of limited information without consideration of liability and causation.

Figure 2 places the claims facilities across this dimension.

4. See Robert B. McKay, Asbestos Property Damage Settlement in a Bankruptcy Setting, 53 L \& Contemp Probs 37 (Autumn 1990).

5. See Francis E. McGovern, The Alabama DDT Settlement Fund, 53 L. \& Contemp Probs 61 (Autumn 1990).

6. See Harvey P. Berman, The Agent Orange Veteran Payment Program, 53 L \& Contemp Probs 49 (Autumn 1990). 
Figure 2

Facilities Are More or Less Similar to Litigation

$\begin{array}{cccccccc}\text { Asbestos } & \text { Center for } & \begin{array}{c}\text { Original } \\ \text { Manville }\end{array} & \text { Dalkon } & \begin{array}{c}\text { Reorganized } \\ \text { Manville }\end{array} & \text { Manville } & \text { Olin } & \text { Agent } \\ \text { Claims } & \text { Claims } & \text { Personal } & \text { Shield } & \text { Personal } & \text { Property } & \text { Olin } \\ \text { Facility } & \text { Resolution } & \text { Injury } & \text { Trust } & \text { Injury } & \text { Damage } & \text { DDT } & \text { Orange }\end{array}$

Thorough discovery
Individualized damage payments
Defenses/causation at issue
Full compensation if liability
Adversarial
Full judicial appeals

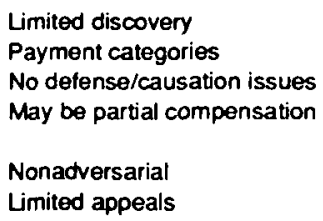

The ACF and the CCR follow the most litigious practices in settling claims. Although the ACF initially explored less adversarial means for determining settlements and offered claimants the use of alternative dispute resolution, the ACF and the plaintiffs' bar never escaped an adversarial relationship. Instead, the ACF was generally seen as functioning like a well-run insurance claims operation. The CCR has also operated in an adversarial posture, but somewhat less aggressively than the ACF.

At the opposite end, the Agent Orange Settlement Fund has differed most from a litigation model. The Fund makes payments for two categories of claims: disabilities and deaths of veterans who were exposed to Agent Orange. Payment amounts differ between these two categories but are the same amount for everyone within each category. Claimants do not have to establish that Agent Orange caused disability or death, but neither can they get increased compensation for severe injuries or stronger causal arguments.

The other facilities fall between these extremes on this dimension of litigation-like compensation processes. Like the Agent Orange Fund, the DDT Claims Facility makes set payments for a limited category of injuries without considering issues of causation or severity. But, unlike the Agent Orange Fund, payments through the DDT Facility vary among diseases, reflecting the likelihood that litigation might have established that a type of disease was caused by DDT. The Manville Property Damage Trust adds one more element of litigation, allowing payments to vary with a claimant's damages. Claimants facing greater losses get greater payment. These three facilities-the Agent Orange Fund, the DDT Facility, and the Manville Property Damage Trust-all differ from litigation in one critical way: compensation does not approach what claimants might expect to receive as full recovery through litigation. Because of serious questions about liability and causation for the Agent Orange and DDT litigations, the global settlements in each provided funds that were far less than injury claims. In turn, payment for each individual claim reflected this compromise: claimants did not have to prove causation, but they did not get much money. Payments 
for Manville property damage claims were limited because the corporation and its creditors decided that personal injury claimants should have a preference for the limited available funds. ${ }^{7}$

The Manville Personal Injury Settlement Trust and the Dalkon Shield Claimants Trust present the most interesting compromises along this dimension. Each trust must distribute a corpus exceeding $\$ 2$ billion to hundreds of thousands of claimants. To save time and money and simply to accomplish this daunting responsibility, both trusts attempt to reduce the issues, information requirements, and adversarial quality in providing compensation. But both trusts are drawn toward a litigation-like process. The previous litigation had established ranges of values for claims and features of claims that increase or decrease settlements of asbestos and Dalkon Shield claims. Plaintiffs' lawyers expected that the trusts' settlements would continue to reflect this prior experience. They expected, on the one hand, that meritorious cases would be fully compensated and, on the other, that little money would be given to claims with questionable liability or weak evidence of causation in order to prevent dissipation of the trusts' limited assets. Of course this posture required each trust to obtain and consider detailed information about liability and causation for each claim. It also maintained the adversarial nature of litigation as plaintiffs' lawyers and the trusts argued about the appropriate compensation.

The bankruptcy plans that created each trust addressed this tension between litigation and expedient claims processing in different ways. The $\mathrm{A}$. H. Robins bankruptcy plan allowed Dalkon Shield claimants to choose the claims process to be applied to their claims. Figure 3 places each of the claimants' options along the dimension of litigiousness.

Figure 3

Dalkon Shield Trust Operates in Three Different Ways

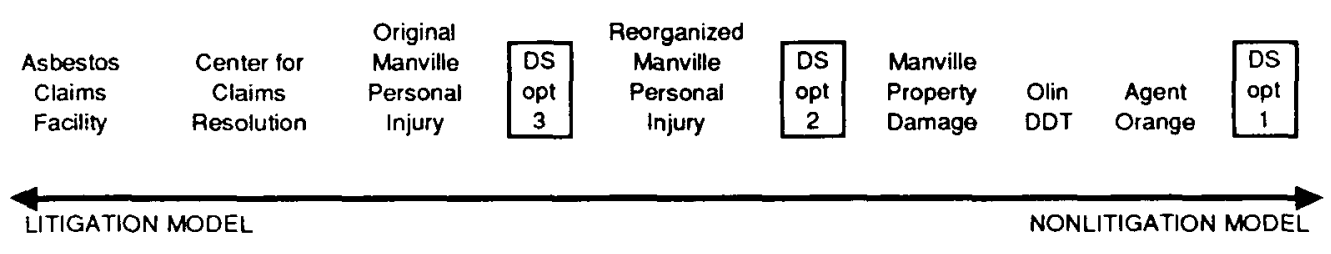

Thorough discovery

Individualized damage payments

Defenses/causation at issue

Full compensation if liability

Adversarial

Full judicial appeals
Limited discovery

Payment categories

No defense/causation issues

May be partial compensation

Nonadversarial

Limited appeals

7. Manville Corporation Second Amended and Restated Plan of Reorganization and Related Documents as Executed and Consummated at Plan Consummation C-324, C-325 (November 28, 1988) ("Second Amended Plan"). 
Option 1 is the most extreme non-litigation process within any of the claims facilities discussed in this symposium. Under this option, a claimant who states that she used the Dalkon Shield can receive $\$ 725$ without having to provide any information about a possible injury. Processing of Option 1 claims involves no discovery, no issue of liability, causation, or even injury, and automatic, minimal payment. ${ }^{8}$

Options 2 and 3, however, involve more of a litigation process. Under these options, claimants receive larger payments if they supply evidence of Dalkon Shield use and an injury enumerated in the plan. Option 2 requires nothing other than this. It provides for payments up to several thousand dollars without requiring a showing of, or requiring the Trust to consider, the most complicated litigation issue: that the Dalkon Shield caused the claimants' injuries. Thus, claimants do not have to satisfy the requirements of litigation. But in turn they receive payments that might be no more than a small percentage of what they would have received through litigation.

As described in the A. H. Robins plan of reorganization, Option 3 appears close to the litigation model. Each case must be considered separately and fully, including issues of causation, injury severity, and defenses, and claimants are fully compensated. The process is adversarial, with a right to trial if a settlement cannot be reached. Formally, this option differs only slightly from ordinary litigation in that the reorganization plan prevents the Trust from contesting culpability while eliminating punitive damages. At least as it has operated to date, however, Option 3 is far from litigation. The Dalkon Shield Trust has adopted procedures for Option 3 that it sees as critical to its objectives of providing expeditious and even-handed compensation. In doing so, it has shifted the compensation process away from an ordinary process of litigation. The Dalkon Shield Trust controls the process. Claimants must complete a specified form and submit all medical records that the Trust determines to be relevant. Failure to satisfy these requirements will slow processing, reduce the value of a claim, and possibly forfeit a claimant's place in queue. Such threats about timing are potent given that the Trust still faces over 80,000 claims but processes claims at the rate of only 15,000 per year. ${ }^{9}$ When it makes settlement offers, the Trust has taken the position that it will not negotiate these "best and final" offers, ${ }^{10}$ nor will it

8. This was not the first offer of minimal payments for release of claims in mass tort litigation. Defendants in the Kansas City Skywalk litigation gave $\$ 1,000$ payments for full releases from persons who could give evidence of being in the lobby of the Hyat Crowne Plaza at the time of the accident. More than 1,000 persons accepted the offer. Hyatt Litigation Could Set Pattern for Disaster Cases, Nat'l L J 3, 26 (January 24, 1983). Persons receiving such payments did not need to show injuries. Id.

9. Description of the effects of incomplete records and of the Trust's progress with claims are from 8 Claims Resolution Report: A Newsletter of the Dalkon Shield Claimants Trust (November 1990). In this newsletter, the Trust declines to project its future volume and schedule of processing claims, contending that the volume of claims processing will increase as more personnel are added and trained. Id at 1,3 .

10. Id at 2. The Trust asserts that its offers reflect the historic values of Dalkon Shield claims. Many plaintiffs' lawyers agree with that assertion in cases of injuries clearly caused by the Dalkon Shield, but do not believe that offers are equal to historic values where causation or documentation is less clear. The Trust argues that if it makes offers of historic values as well as negotiates its offers, it 
explain them. ${ }^{11}$ Claimants who find the offers unacceptable do not have a clear or expeditious remedy. Settlement conferences, the first review step prescribed by the reorganization plan, were not scheduled until ten months after the Trust's first offers. Claimants who submit new information for this review risk even further delay by losing their place in line. ${ }^{12}$ Even when they reach settlement conferences, claimants cannot approach these conferences in an adversarial fashion. The Trust will modify an offer only if it made a mistake in evaluation. Since the Trust will not reveal the bases for its offers, however, claimants and their lawyers have little guidance in arguing that the Trust made a mistake.

At least through the time of this writing, plaintiffs' lawyers have had little incentive or power to challenge the Dalkon Shield Trust's control over the compensation process. Plaintiffs' lawyers have seen (and accepted) Trust offers on many claims that are at least equivalent to prebankruptcy settlements. These lawyers have been reluctant to challenge the Trust because they have been satisfied with the Trust's treatment of many of their claims. In any event, claimants who are dissatisfied with the Trust's treatment of their claims cannot expect timely satisfaction in court. Although Dalkon Shield claimants maintain the right to a jury trial and can obtain judgments that exceed the Trust's offer, they will not receive any more money than the Trust offered unless and until all other claimants have been paid. ${ }^{13}$

As it has operated during the last two years, the compensation process of the Manville Trust has been far closer to litigation than any of the options offered by the Dalkon Shield Trust. The Manville Corporation reorganization plan gave the Trust little help in developing nonlitigious procedures for settling claims. Although the Manville Corporation and its creditors agreed under the plan to remove punitive damages as an issue, ${ }^{14}$ and attempted to simplify information gathering by specifying information that claimants must submit and limiting medical information that the Trust could require, the plan kept the Trust in an active litigation posture by encouraging rather than discouraging trials. Because Manville was the first claims resolution facility to be created through bankruptcy proceedings, plaintiffs' lawyers were adamant in preventing any obstruction to jury trials. As a result, unlike the $\mathrm{A}$. $\mathrm{H}$. Robins plan, the Manville reorganization plan created no disincentives for trials.

will settle cases for more than their historic values, possibly jeopardizing the Trust's ability to pay subsequently settled claims. Id.

11. The Trust's offers apparently are based on formulae or guidelines for calculating claims values. The Trust argues that detailed justification of offers might disclose these formulae, allowing plaintiffs' lawyers to manipulate claims to maximize their values.

12. To avoid duplicative reconsideration of claims, the Trust will review newly submitted information only if it could not have reasonably been discovered when the claim was originally submitted. The Trust will review newly submitted information even if a claimant could have discovered the information previously, but the Trust will assign the claimant a new queue number and review the claim only when this new queue number is reached. Id.

13. In re A.H. Robins, Inc., 880 F2d 694 (4th Cir 1989).

14. Second Amended Plan at C-324 (cited in note 7). 
Two additional features of the Manville reorganization plan kept the Trust in litigation, setting the general posture for its compensation process. First, plaintiffs could jump their place in the claims processing queue by going to trial. The Manville plan required the Trust to process claims in the order in which the claims were filed, ${ }^{15}$ but, as an exception to this order, the Trust negotiated and offered settlements in any case going to trial, attempting to lessen its trial expenses and exposure. Therefore, even claimants with late filing dates were able to receive early processing and payment by going to trial. Second, the plan allowed other asbestos defendants to implead the Trust in litigation brought against them by any person who had also filed a claim against the Trust. The Trust was impleaded tens of thousands of times.

These provisions not only forced the Manville Trust to expend enormous amounts of time and money on litigation, but they also forced the entire compensation process into a litigation mode. Claims had to be prepared for trial, not simply evaluated for settlement. Local trial counsel participated in discovery to establish the Manville share of liability in each case. Local counsel, rather than Trust claims personnel using simpler bases of evaluation, also often negotiated the values of injuries and the Manville share of liability, based on the discovery and other traditional bases for evaluating claims.

In short, unlike the Dalkon Shield Trust, the Manville Trust never gained sufficient control of the compensation process to achieve a less litigious approach. Because it feared that it would face more trials if it aggravated plaintiffs' lawyers, the Trust never moved aggressively toward a process less like litigation. Because the Trust did not even assert the reorganization plan's requirement that claimants provide information on a proof of claim form, it was forced to consider a claim when its queue number was reached whether or not the claimant had submitted sufficient information to process the claim. Where information was lacking, the Trust either had to pester the claimant's lawyer for the needed information, develop the information itself, or settle the case without it.

The unanticipated volume of claims against the Manville Trust also impaired its ability to pursue a less litigation-like claims process. By November 1990, within two years of its implementation, the Trust had received 150,000 claims, 50 percent more than the number predicted by the reorganization plan for the entire life of the Trust. This volume swamped the Trust's ability to process each claim expeditiously and depleted the Trust's assets, leaving it with insufficient assets to pay claims fully as the reorganization plan promised. In April 1990, the Trust announced a plan under which it would pay each claimant only 40 percent of the settlement value at the time of settlement, deferring the remaining 60 percent. But this plan and the Trust's proclamations of penury only increased the number of trials, driving the Trust further into litigation.

15. This is called the "FIFO" (first-in-first-out) queue. Id at Annex B $§$ 1.A.2. 
In part because the Trust could not escape the excessive cost of litigation and a litigation-like claims process, the original Manville compensation process proved unworkable. Because the Trust would have been unable to pay judgments that might come out of a consolidated trial in his court, Judge Jack B. Weinstein ordered a temporary stay of payments by the Trust in July 1990. ${ }^{16}$ In October 1990, following its own motion, the Manville Trust was determined to be a limited fund under Federal Rule $23 \mathrm{~b}(1)(\mathrm{B})$, incapable of paying all claimants 100 percent of the value of their claims as required by the Manville bankruptcy plan. ${ }^{17}$ The Manville Trust and its compensation process were reorganized through settlement of a mandatory class action filed by a group of claimants under Federal Rule $23 \mathrm{~b}(1)(\mathrm{B}) .{ }^{18}$ As of this writing, the settlement was pending with the district court.

The reorganized Manville distribution plan is intended to produce a less litigious compensation process. Claimants and co-defendants retain the right to try claims against the Trust, but the reorganized plan eliminates most incentives for trial. A claimant cannot accelerate payment by going to trial before the Trust reaches the claimant's place in queue. ${ }^{19}$ Because the plan limits the amount that can be paid on any judgment until the unlikely event that all other claims are paid in full, payments are also unlikely to be increased by going to trial. ${ }^{20}$ The reorganized plan also eliminates co-defendants' power to implead the Trust and prevents any beneficiary of the Trust, claimant or co-defendant, from directly or indirectly involving the Trust in trials. ${ }^{21}$

In eliminating the advantages that claimants might expect from trial, the reorganized plan turned the impact of the Manville Trust's distressed financial situation from a factor that encouraged trials to a factor that should make the settlement process less litigious. The Trust's limited resources reduce both the Trust's and plaintiffs' incentives to fight for the last dollar of settlement. Because plaintiffs will receive only a fraction of the values of their settlements, that which is at stake in each dispute decreases. For example,

16. In re Eastern and Southern Dist. Asbestos Litigation, 1990 WL 115761 (ED NY July 9, 1990).

17. In re Johns-Manville Corp., 82 B 11656-76, at 20-21 (ED NY November 3, 1990), cited in In re Joint Eastern and Southern Dist. Asbestos Litigation, 120 BR 648 (E \& SD NY 1990).

18. In re Joint Eastern and Southern Dist. Asbestos Litigation, 120 BR 648.

19. Id at Appendix C, 673 ("Stipulation of Settlement").

20. Id at 673-74. This provision of the reorganized Manville plan follows and is similar to that of the A. H. Robins bankruptcy plan. Dalkon Shield claimants can immediately collect trial judgments up to the amount offered by the Dalkon Shield Trust, but if a judgment exceeds the offer the claimant will collect such excess only if and when the Trust has paid settlements to all other claimants. The right to collect trial judgments under the Manville plan is more complicated. Under the reorganized Manville Trust distribution plan, a trial judgment does not entitle a claimant to immediate payment, but rather determines the amount of a claimant's share in the pro rata pool. Id at 673. A claimant's share in the pool (identified as "Pool A" in the plan) will not exceed the maximum value established by the plan for the claimant's injury, unless either the Trust or an arbitrator determined that the claim was extraordinary (in which case the claimant's share will be the greater of the Trust's offer or the arbitration award). If a judgment exceeds this maximum, the excess becomes the claimant's interest in a second pool ("Pool B"), which receives funds only if and when all claims in Pool $\mathrm{A}$ have been fully compensated. Id at 674.

21. Id at 676-77. 
where the Trust offers $\$ 60,000$ and a plaintiff demands $\$ 75,000$, the parties would argue not over a difference in payment of $\$ 15,000$ but over some lesser amount. If the Trust is able to pay only 40 percent of the value of settlements, then this disagreement involves $\$ 6,000$. Furthermore, because payments are in installments through the pro rata pool, ${ }^{22}$ this difference would be paid over years, with a probable difference of less than $\$ 2,000$ in the initial payment.

The reorganized Manville plan also creates incentives for both the Trust and plaintiffs to be less litigious in negotiating claims. In responding to demands for speedier processing of claims, the plan now imposes requirements that can be met only by simplifying the settlement process. The plan requires such a high volume of claims processing - settlement of as many as 16,000 cancer and serious asbestosis claims before the Trust can make a first distribution under the new plan-that the Trust will need to minimize the time and attention it gives to each claim. This also gives plaintiffs' lawyers significant incentive to expedite claims processing, because their clients will receive no payments until this requirement is satisfied.

The plan tries to support this changing set of incentives by offering means to establish a less litigation-like distribution process. For each type of asbestos-related disease, the plan specifies the "midpoint" value that most claims should receive and the maximum values that any claim can receive. ${ }^{23}$ It specifies factors that will affect the values of claims within this range. ${ }^{24}$ Finally, the plan authorizes the Trust and a group of plaintiffs' lawyers to modify the distribution plan to assure that its objectives are achieved. ${ }^{25}$

These changes in the Manville Trust's distribution process provide the basis for a less litigious process. Figure 3 suggests that the reorganized settlement process for the Manville Trust is somewhere between the Dalkon Shield Trust's Options 2 and 3. However, much depends on how the Manville Trust operates under this new plan. Comparisons of the experiences of the Dalkon Shield and the original Manville Trust suggest that the reorganized Manville Trust will succeed in establishing a less litigation-like claims process only if it controls the litigation process.

\section{Other Methods for Distributing Compensation}

In looking further at the timing, costs, and fairness of distributions by claims facilities, it is useful to consider alternative means for distributing

22. The Manville Trust now has more than 130,000 claims but will not receive most of its income until the future. Therefore, the plan attempts to spread available money broadly among claimants as they settle. It establishes an annual pro rata distribution in which all income available for distribution is parcelled out to each claimant so that each claimant receives a share proportional to the unpaid balance of his or her claim as a fraction of the total of all unpaid claims. Id at 674-76, $\S \mathbf{F}$.

23. Id at 672, 680. Payment can exceed the maximum for an injury only if it is an "extraordinary" claim meeting conditions indicated in the plan. Id.

24. Id.

25. Id at 678 . 
compensation. Figure 4 places two important alternatives-workers' compensation systems and group settlements-along the same dimension of litigiousness of the distribution process. Again, both alternatives are a mixture of litigation and nonlitigation.

Figure 4

Distribution Function Should Be Compared to Global Settlements or Other Distribution Mechanisms

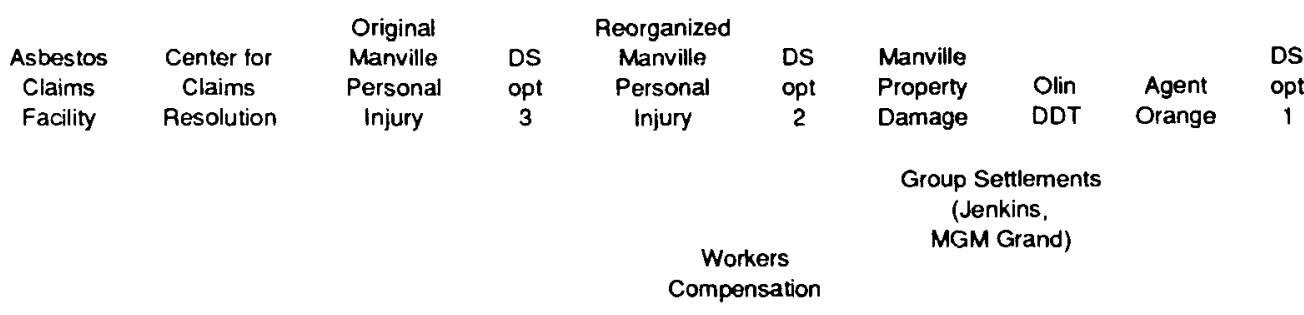

LITIGATION MODEL

NONLITIGATION MODEL

\author{
Thorough discovery \\ Individualized damage payments \\ Defenses/causation at issue \\ Full compensation if liability \\ Adversarial \\ Full judicial appeals
}

\author{
Limited discovery \\ Payment categories \\ No defense/causation issues \\ May be partial compensation \\ Nonadversarial \\ Limited appeals
}

Workers' compensation systems share the basic objectives of claims facilities: to avoid litigation and provide efficient compensation. The limited compensation provided by these systems and their use of payment categories make them dissimilar to litigation. But the systems have become increasingly adversarial as disincentives to litigation have been weakened.

Each of the claims resolution facilities considered here came out of mass litigation. But other mass litigation has resulted in global settlements where distributions were determined by plaintiffs' lawyers rather than by a formal claims facility. In some respects, such distributions of group settlements reflect litigation. Differences in compensation among claims are based, in part, on matters that affect values in litigation, such as the severity of a claimant's damages and the strength of the liability issues for each claim. But the distribution procedures are nonlitigious. All plaintiffs and, in turn, their lawyers compete for the settlement proceeds. In principle, the judicial review of settlements allows dissatisfied plaintiffs an appeal. ${ }^{26}$ But in fact disagreements about shares have been worked out by the parties through compromise and accommodation, often while the settlements were being negotiated with defendants.

26. This power is sometimes exercised, as when Judge Robert Parker changed the amount of compensation for several members of the Jenkins class action for asbestos injury claims. Mark A. Peterson \& Molly Selvin, Resolution of Mass Torts: Toward a Framework for Evaluation of Aggregation Procedures (RAND, 1988) (N-2805-ICJ). 


\section{A. Variations and Fairness in Payments}

Competing notions of fairness underlie the different ways that the claims facilities allocate payments among claimants. Figures 5 through 7 illustrate hypothetically 27 how the facilities distribute money among personal injury claimants. ${ }^{28}$ The simplest sense of fairness is that everyone gets the same amount.

Figure 5

Variance of Payments Is Greater with a Litigation Approach

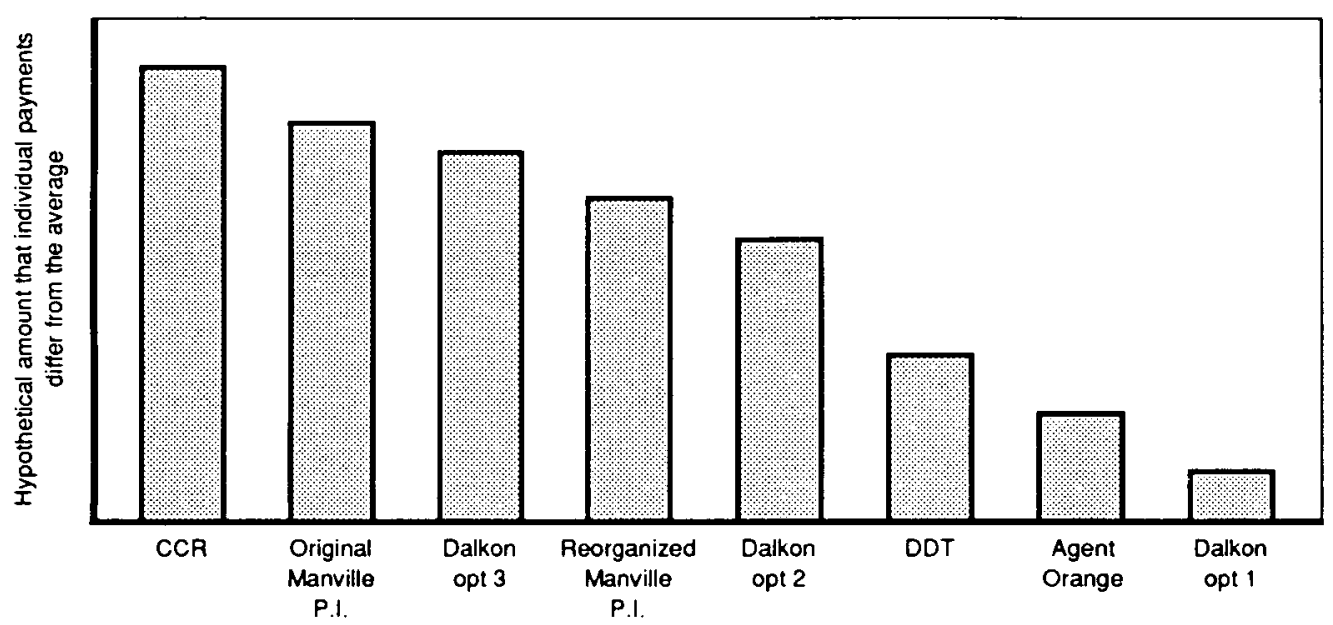

As Figure 5 suggests, payments vary the least in claims facilities that take a nonlitigious approach. This equivalence among payments reflects the judgment that there is little basis for differentiating among claims when, for example, there is inconclusive evidence that any injury was caused by the particular product, such as Agent Orange, or where no evidence of injury is submitted, such as Dalkon Shield Option 1. Undifferentiated payments also seem appropriate in claims facilities that can provide only minimal compensation, where the cost of differentiating would consume most of the premium that more seriously injured claimants might expect to receive.

Equal, substantial payments do not seem fair when claimants have losses of greatly differing severity. An expectant mother who lost a child and nearly died from a septic abortion or a childless young woman who underwent a hysterectomy both suffered far greater losses than a woman who had mild PID

27. While it would be interesting to compare these hypothetical figures with actual data on payments made by each facility, such data are available only for the nonlitigation approaches of the Agent Orange Program and the Dalkon Shield Option 1. Facilities adopting a more litigious posture refuse to release data about variability and correlates of payments because they fear that the release of such information would disadvantage them in any continuing litigation. Despite this concern, some information about the original Manville Personal Injury Trust became available as a result of the court proceedings involving the Trust's status as a limited fund.

28. Comparisons with the Manville Property Damage Trust are less instructive, because of the basic difference in personal injury and property damages. 
without sequelae. ${ }^{29}$ Equal payments among all these claimants would either be too much for the victim of simple PID or inadequate for the other, more seriously injured claimants. Both of these inequities will occur, however, when a facility has enough money to compensate the level of the least serious injuries but not enough to compensate all claimants fully. ${ }^{30}$

A second notion of fairness emphasizes the compensatory objectives of claims facilities, that is, tying payment amounts to claimants' losses.

FigURE 6

Payments under Mixed Approaches Will Be Closer to Amounts NEEDED FOR COMPENSATION

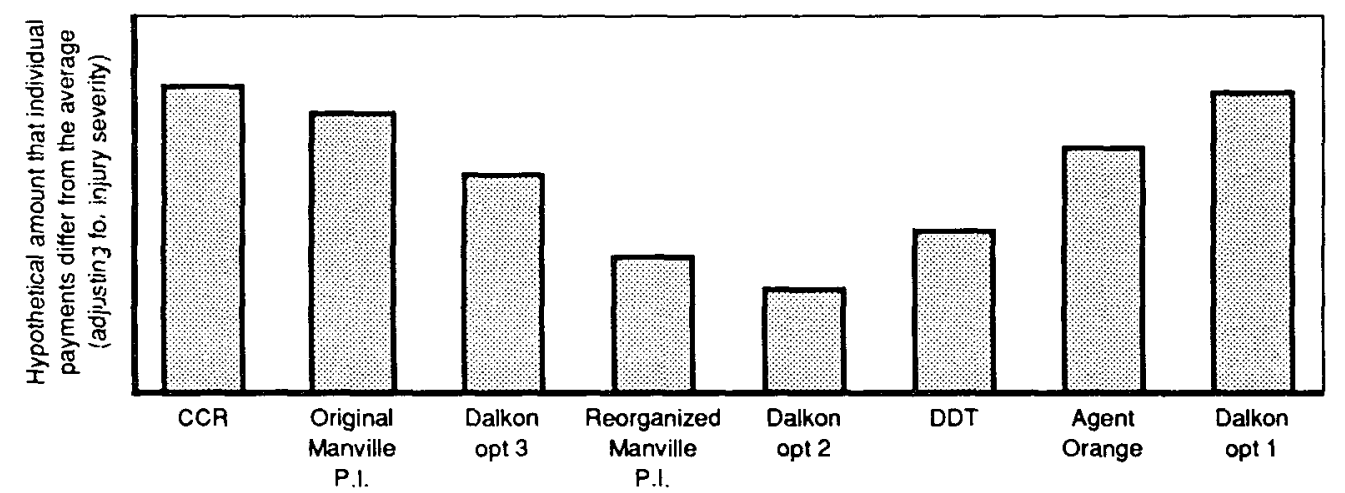

Figure 6 suggests how well payments by the various claims facilities correspond to the seriousness of claimants' injuries. The figure borrows an intuition from multivariate statistical analyses, suggesting how much payments vary among claimants over and above the variation that is needed to reflect the differing seriousness of claimants' injuries (that is, after "adjusting for" the differences in severity of injuries). Payments by the least litigious procedures, which make equal payments or payments geared only slightly to seriousness, diverge substantially from payments based on the seriousness of injuries: slightly injured claimants receive far more relative to the seriousness of their injuries than seriously injured plaintiffs. Payments under the most litigious procedures are also highly variable, because those payments are affected by factors other than the seriousness of injuries. Depending upon issues of liability and causation, a seriously injured claimant might receive less

29. Claims for PID, pelvic inflammatory disease (infections), and claims for sterilizing surgery were frequent among Dalkon Shield claimants. Francis E. McGovern, The Cycle of Mass Tort Litigation (Yale Program on Civil Litigation Working Paper No 122, May 1990), Claims for septic abortions and infected pregnancies were less frequent, but were the only claims for deaths among Dalkon Shield users. Morton Mintz, At Any Cost 156-58 (Pantheon, 1985).

30. An additional issue of fairness was raised by the reorganized plan for the Manville Personal Injury Settlement Trust. Under that plan, claimants with cancer or grave asbestosis receive payments more quickly than other claimants, a situation that creates a greater risk of low payment for less seriously injured claimants. If the Trust is unable to pay all claimants at least $45 \%$ of their settlement amounts, the most seriously injured claimants will receive a greater percentage of their settlements. This arrangement was the subject of a challenge by a minority of plaintiffs' lawyers. Asbestos Litigation Reporter 22478-79 (February 15, 1991). 
than a claimant with slight injuries. Among the claims facilities considered here, payments under Dalkon Shield Option 2 seem to be most closely tied to the seriousness of injuries. ${ }^{31}$ Option 2 payments are keyed to claimants' injuries but ignore matters of liability and causation that affect payments under Option 3.32

A third notion of fairness emphasizes that claims facilities derive from our tort system, so that payments should reflect the objectives and expectations within that system. Entities that fund the facilities will not contribute more funds than would be needed to provide the expected level of compensation to persons who could have claimed in tort. Therefore, if a facility makes payments to persons who could not have filed a legal claim, or if it pays more than a claimant might have received through the tort system, other claimants will receive less than they might have through litigation. To avoid this unfairness, payment amounts should be affected by the seriousness of a claimant's injuries to the same degree tort compensation would have been affected and by the likelihood that the entity funding the claims facility caused and would have been liable for the claimant's injuries. Thus less money should be given to an asbestos claimant who smoked cigarettes so that more might be given to a similar claimant who did not smoke.

31. The seriousness of an injury is not a sufficient basis for compensation by any of these facilities. Each facility is concerned with only a subset of injuries that might have some association with the basis of liability in the underlying litigation. Thus, for example, none of the facilities considered here compensates claimants who have traumatic quadriplegia, a catastrophically serious injury, because it is not a possible effect of exposure to any of these products.

The Agent Orange facility compensates the broadest set of serious injuries: all death and disability other than self-inflicted or other traumatic causes. Berman. 53 1. \& Contemp Probs at 54 55 (cited in note 6 ).

32. These observations on fairness pertain only to the relative size of payments within each of the Dalkon Shield options, that is, that among all Option 2 payments, the relative amounts reflect the seriousness of injuries. A different issue involves the faimess of the level of payments to Option 2 claimants in comparison to payments under the other options, a matter addressed below. 
Figure 7

Payment Under a Litigation Approach Will Most Closely Approximate Reflect Defenses, Causation, and Other Legal IsSues

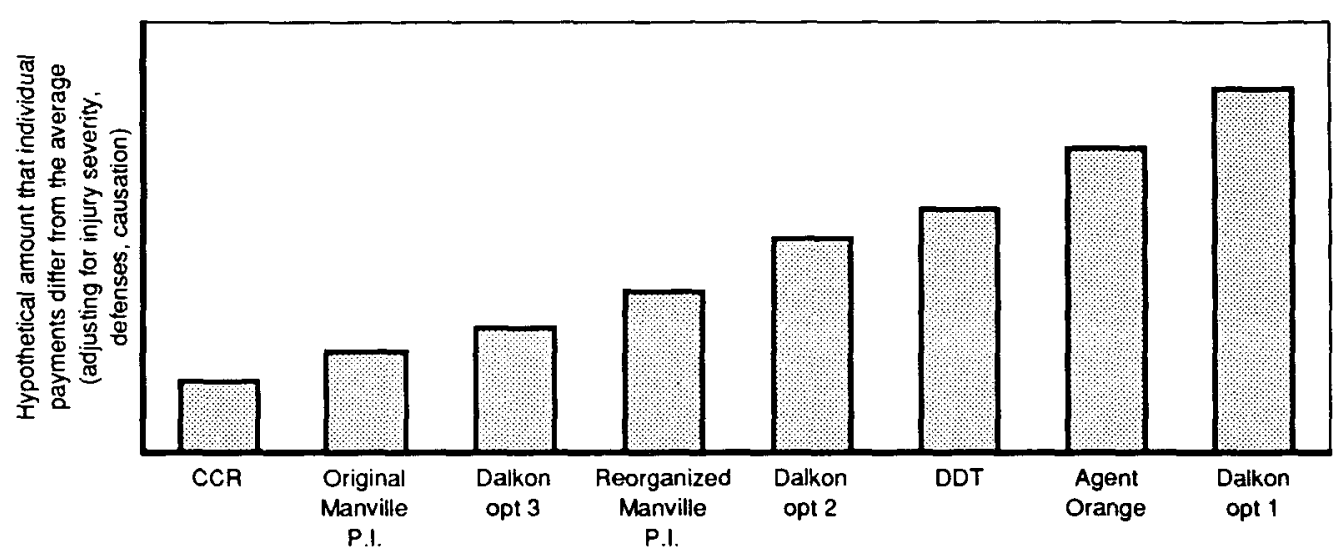

Of course payments through facilities with the most litigation-like distribution processes should most closely satisfy this notion of fairness (Figure 7), because these facilities continue to consider the issues that drove the values of claims during litigation. The flat payments of nonlitigious processes fall furthest from this notion of fairness, since they fail to consider a multitude of issues that affect the values of litigated claims.

The tensions among these alternative notions of fairness are shown in decisions of the Dalkon Shield Claimants Trust. Although the Trust provided three options geared to each of these notions of fairness, the Trust and plaintiffs' lawyers seem to have disagreed considerably on the payment amounts under Options 2 and 3 . While the Trust was developing its payment procedures, there were indications that it would make substantial payments under Option 2. Significant Option 2 payments would have encouraged claimants to take that option rather than the more costly and litigious Option 3 , and it would have given primacy to the Trust's compensatory objectives. Many users of the Dalkon Shield suffered infections, infertility, ectopic pregnancies, surgeries, and other injuries associated with use of the device. Often there was little certainty about whether or not the Dalkon Shield caused a particular claimant's injuries, a problem that was exacerbated because most women stopped using the device fifteen years before the Trust began. In any event, whether they were right or wrong, many claimants thought their injuries were caused by the Dalkon Shield, and the weight of these injuries was the same whether or not the injury was caused by the Shield.

Plaintiffs' lawyers objected to suggestions that the Trust might make significant Option 2 payments. They were concerned that such payments would reduce funds needed to compensate fully claimants with strong legal claims. Many Dalkon Shield users became infertile or had surgery because of fibroid tumors, cancer, or other medical problems that could not have been 
caused by the Dalkon Shield. Their substantial compensation under Option 2 , however, would have been paid by women whose injuries were more likely caused by the Shield.

In the end, the Dalkon Shield Trust put its money behind Option 3. Option 3 claimants, whose claims would have been strong in litigation, have received offers comparable to settlements during litigation. Option 2 claimants have received payments that are only a small fraction of this full compensation.

\section{B. The Costs of Claims Resolution}

Claims facilities are intended as efficient distributors of compensation that will incur far fewer expenses than ordinary litigation. Figure 8 compares the transaction costs consumed by each claims facility to the defense costs for three types of litigation. ${ }^{33}$

Figure 8

Percent of Payout Going for Administrative/Defense

EXPENSES

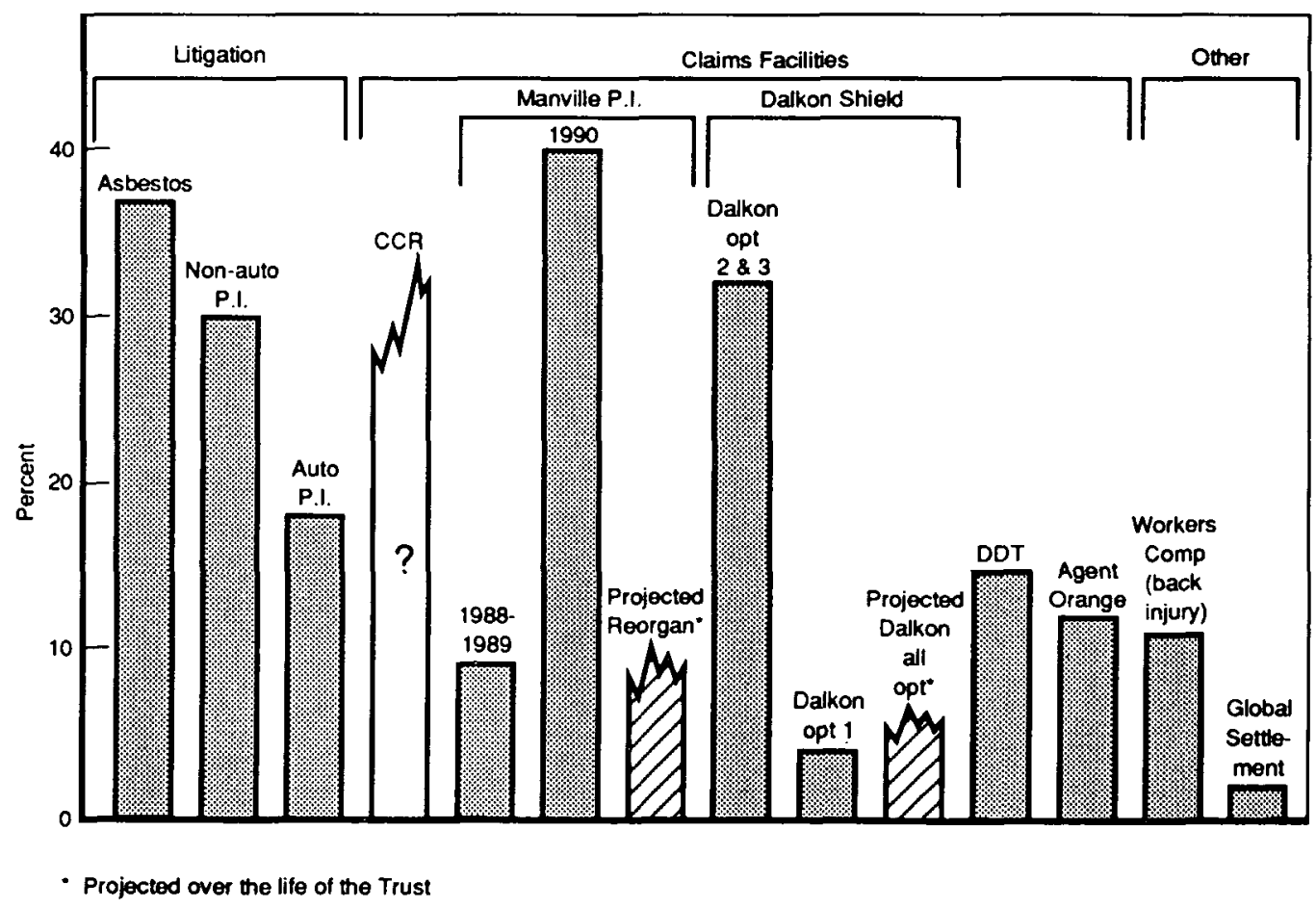

RAND's Institute for Civil Justice determined that prior to Manville's bankruptcy petition in 1982, defense costs for asbestos litigation consumed 33 percent of defendants' total expenditures on the litigation (that is, the sum

33. The figure shows: [Operation + Litigation costs] $\div$ [Compensation to claimants + Operation + Litigation Costs]. 
of compensation and defense costs) ${ }^{34}$ This percentage has come to be routinely cited as the level of defense costs in mass tort litigation, although the percentage might be somewhat less in mass litigation that does not involve the significant cross-litigation among co-defendants and their insurers that characterizes asbestos litigation. Outside of mass tort litigation, defense costs are somewhat less. A second Institute for Civil Justice study estimated that defense costs represented about 30 percent of expenditures in nonautomobile personal injury litigation, and about 18 percent in automobile personal injury litigation. ${ }^{35}$

Although most claims facilities appear to be more efficient than this, estimates of their transaction costs can be difficult to determine. The Center for Claims Resolution withholds information about its expenditures on compensation and on costs because of its strategic concerns about the ongoing litigation. ${ }^{36}$ The Dalkon Shield Trust reports its overall costs and total compensation, but does not allocate costs among the three options. ${ }^{37}$

The expenses of claims facilities that pursue a litigation-like posture can be unstable. ${ }^{38}$ This instability is striking for the Manville Personal Injury Trust. In its first year of operation, operating and litigation expenses for the Trust were only 9 percent of the sum of disbursed compensation and expenses. During this year, the Trust distributed an enormous amount of compensation but had little litigation cost. The Trust's expenses accelerated sharply in its second year as claimants pursued trials to get earlier compensation and avoid the Trust's insolvency, the onset of which was becoming increasingly apparent. The Trust's second-year expenses represented 40 percent of its total disbursements, surpassing the level spent on defense by defendants engaged in active asbestos litigation. The Manville Trust's extraordinary costs were still growing when Judge Weinstein intervened, setting in motion the reorganization that stopped this hemorrhage of expenses. ${ }^{39}$ Projected expenses under the reorganized plan remain speculative-the plan is still under court review-but will likely fall in a range of 5 to 10 percent of the Trust's total disbursements.

The most important cost savings arise when trials and trial preparation are proscribed or severely limited. As the Manville experience shows, when

34. James S. Kakalik, et al, Variations in Asbestos Litigation Compensation and Expenses (RAND, 1984) (R-3132-ICJ).

35. James S. Kakalik \& Nicholas M. Pace, Costs and Compensation Paid in Tort Litigation (RAND, 1986) (R-3391-ICJ).

36. Personal communication by Lawrence Fitzpatrick, president and chief executive officer of the Center for Claims Resolution, April 1990.

37. Estimated costs for Option 1 shown on Figure 8 were for early operation of the Trust when Option 1 was the only option offered. Estimates for Options 2 and 3 are based on an allocation of cumulative expenses and compensation, and were derived by subtracting an estimate of expenses attributable to Option 1, based on years in which only that option was offered, from the Trust's reported total expenses when all Options were offered.

38. Again, there is no public information about possible instability in the expenses of the Center for Claims Resolution.

39. The data on expenses and compensation are from documents provided by the Manville Trust for limited fund hearings. 
facilities are drawn into litigation, their costs can be comparable to those of the costs to defendants through the adjudicatory system. Figure 9 looks more closely at this.

FIGURE 9

Percent of Administrative/Defense Expenses Paid to Lawyers

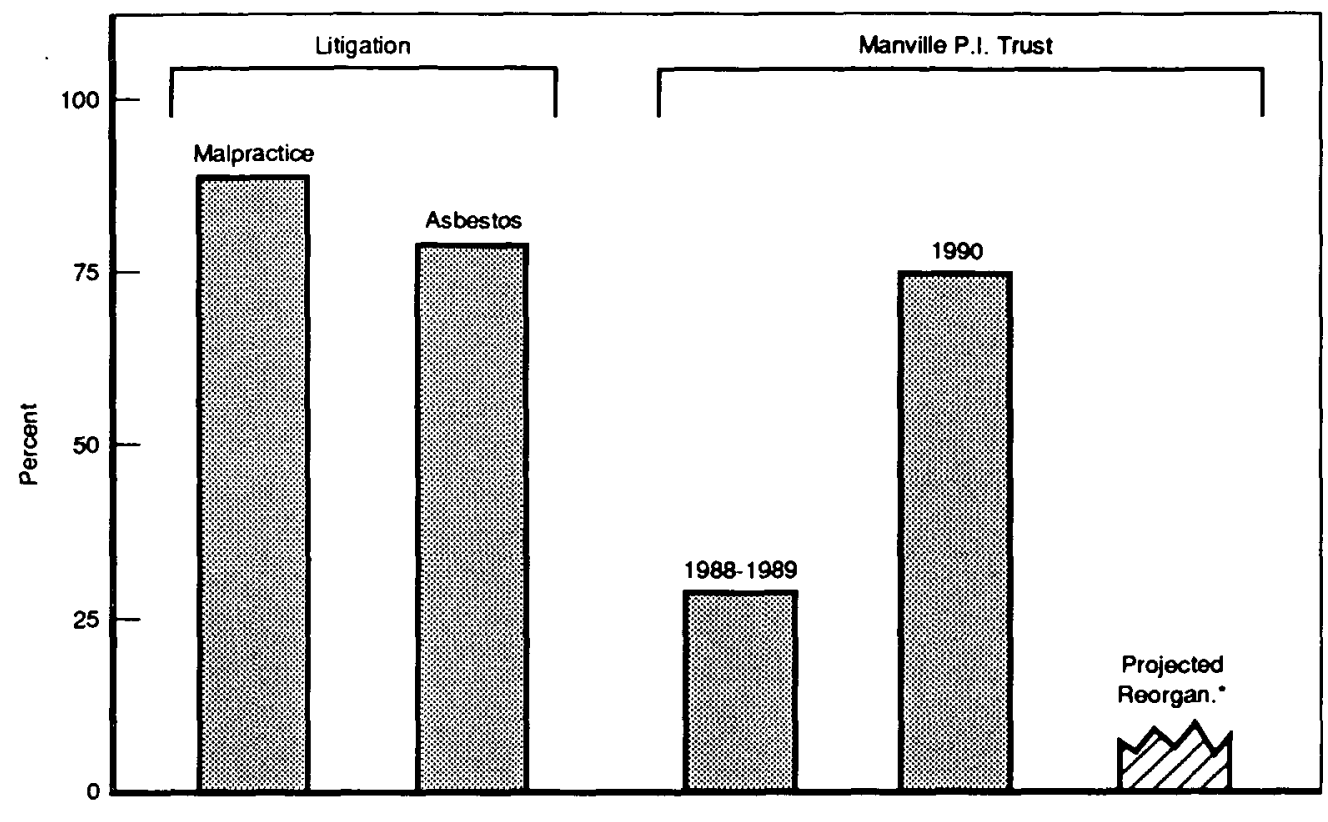

- Projected over the life of the Trust

Figure 9 shows the percentage of total operating costs and defense costs paid to defense lawyers ${ }^{40}$ comparing it for the Manville Personal Injury Trust to general figures for malpractice litigation ${ }^{41}$ and asbestos litigation outside of the claims facility context. ${ }^{42}$ The percentage of overall litigation expenses paid to defense lawyers was only slightly more among malpractice and asbestos defendants who were still engaged in litigation than it was for the Manville Trust during its second year of operation. As noted above, claims facilities do not save money if they cannot control litigation costs.

Returning to Figure 8, it shows that the Dalkon Shield Claimants Trust has not yet had to face trials or spend money on actual litigation. The A.H. Robins bankruptcy plan permits trials only for Option 3 claimants who had a settlement conference with the Trust but rejected the Trust's offer. (As the Trust began making offers on Option 3 cases only in mid-1990 and began scheduling settlement conferences in March 1991, no Option 3 claimants have yet gone to trial.) Expenses represent a high percentage of the Trust's

40. This figure shows: Litigation costs $\div$ [Operations + Litigation costs].

41. Kakalik \& Pace, Costs and Compensation Paid in Tort Litigation (cited in note 35).

42. Kakalik, et al, Variations in Asbestos Litigation Compensation and Expenses (cited in note 34). 
disbursements because the Trust distributed relatively little money (primarily minimal payments to Option 1 claimants) during the period that it was setting up its operations. Although these expenses are a significant percentage of the Dalkon Shield Trust's disbursements, the expenses represent less than the interest earned by the Trust during this period.

The Dalkon Shield Trust projects that its operating costs will run between 5 and 7 percent over the life of the Trust. This projection might be optimistic, however. The level of the Trust's expenditures will depend substantially on the amount of litigation involving the Trust. The rigid posture that the Trust has taken toward its claims will likely encourage many claimants to pursue litigation. The Trust has offered minimal compensation to several groups of claimants who might expect significant trial judgments, such as claimants who can provide evidence of Dalkon Shield but whose medical records do not show such use, or claimants who might have had "silent PID," that is, who manifest sequelae of PID but cannot show acute infections. These claimants must either accept often trivial offers or pursue trial. The A. H. Robins bankruptcy plan provides relatively weak disincentives for such trials. Claimants who reject the Trust's offer and receive a larger trial judgment will not collect the excess of the judgment over the offer unless the Trust has paid all other claimants. But because the Dalkon Shield Trust has $\$ 2.5$ billion, claimants who go to trial have an excellent chance of receiving their full judgment. The major disincentive these claimants face is a delay in payment that is likely to run into a number of years.

Among claims facilities that can avoid trials and trial preparation, it is unclear how much more can be saved by adopting a non-litigation claims process. The automatic, minimal payments of Dalkon Shield Option 1 involve few administrative costs, but that option also pays little to claimants. The real saving from Option 1 is disposing of cases that might otherwise get greater compensation with minimal administrative expense and minimal compensation. The relative costs of other facilities seem to fall within a fairly narrow range. Indeed, the projections for the reorganized Manville Personal Injury Settlement Trust suggest that costs can be sharply limited even among facilities with distribution processes that somewhat resemble litigation. The Dalkon Shield Trust will provide the best evidence of the efficiencies of different approaches when it can compare the costs and compensation from full operation of all three of its options.

As Figure 8 shows, the transaction costs of claims facilities compare favorably to costs of another administrative system, the workers' compensation systems in processing claims for back injuries. It is also worth noting that distribution costs are almost certainly lowest in global settlements such as the Jenkins asbestos class action ${ }^{43}$ or the MGM Grand Hotel fire settlement ${ }^{44}$ where distributions are undertaken by plaintiffs' lawyers under the supervision of courts. But the consensual and informal distributions in

43. See Peterson \& Selvin, Resolution of Mass Torts at 41-42 (cited in note 26).

44. In re MGM Grand Hotel Fire Litigation, 570 F Supp 919 (D Nev 1983). 
these settlements do not seem broadly appropriate. Plaintiffs' lawyers had a relatively easy time distributing the settlement proceeds in Jenkins and MGM where there was enough money to provide generous compensation to all claimants. Agreements among plaintiffs' lawyers might not be so forthcoming where plaintiffs must compete for inadequate or barely adequate funds. Consensual distribution seems impossible in cases involving large numbers of claimants, or even a modest number of claimants, who are not represented by lawyers. Further, unless closely scrutinized, the distributions of global settlements can be subject to abuse. ${ }^{45}$

\section{Timing in Claims Facilities}

Timing is an issue in two respects. First is the time that it takes to establish a facility, to develop a plan and put it into operation. For each of the facilities considered in this symposium, Figure 10 shows the timing from when a settlement, bankruptcy reorganization, or other event created a need for the facility, to the time the facility began operating and making payments.

FigURE 10

Timing: Formation to Distribution

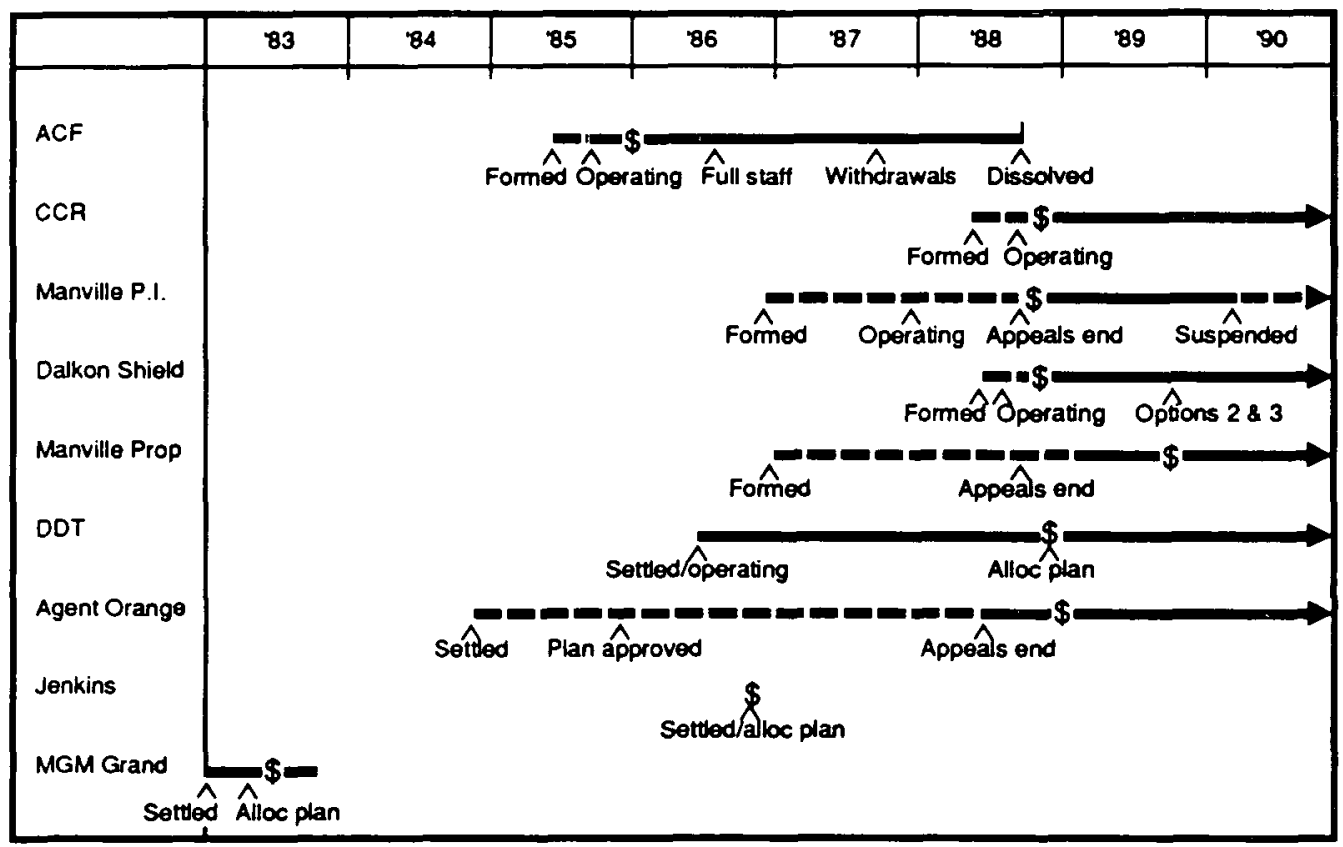

$\$$ indicates when money first distributed

45. Distributions might be made on bases other than the merits of claims. Greater compensation might be made to claimants who have helped lawyers or to claimants of lawyers who control the litigation or who threaten to hold up settlement unless their clients get a premium. In the MGM Grand settlement, approximately $14 \%$ of the claimants received substantial pavments even though they submitted no evidence of injury. Mark A. Peterson, Group Justice, in CPR Legal Program Proceedings 69 (February 1986). 
Each claims facility was a new entity. The length of time to bring each entity into a position to distribute money was significant. Implementation was often delayed for years during court reviews of facilities that grew out of an aggregative legal proceeding, a settlement, or bankruptcy reorganization. For example, implementation delays occurred twice for the Manville Personal Injury Settlement Trust: first during the lengthy appellate review of the Manville bankruptcy plan and second when operations of the Trust were stayed because the original plan proved unworkable.

The A. H. Robins bankruptcy plan mitigated the burden of delay for some claimants when the company provided funds that were immediately distributed to Option 1 claimants. The company was willing to make this early payment because, even if the plan had been overturned by the court of appeals, the company would have had the benefit of low-cost settlements of many claims. The currently pending plan to reorganize the Manville Trust also mitigates the delay during judicial review by allowing the Trust to agree on settlement values in cases involving cancer and other serious injuries during the pendency of any appeal. If the plan is upheld by the courts, the Trust will then be able to make immediate distributions. On the other hand, if the plan is rejected by the court of appeals, the Trust will have valued most of the serious and costly cases it faced, which should help further attempts to rescue the Trust even if those values are not binding on claimants.

FIGURE 11

Number of Claims Resolved by Time to Resolve

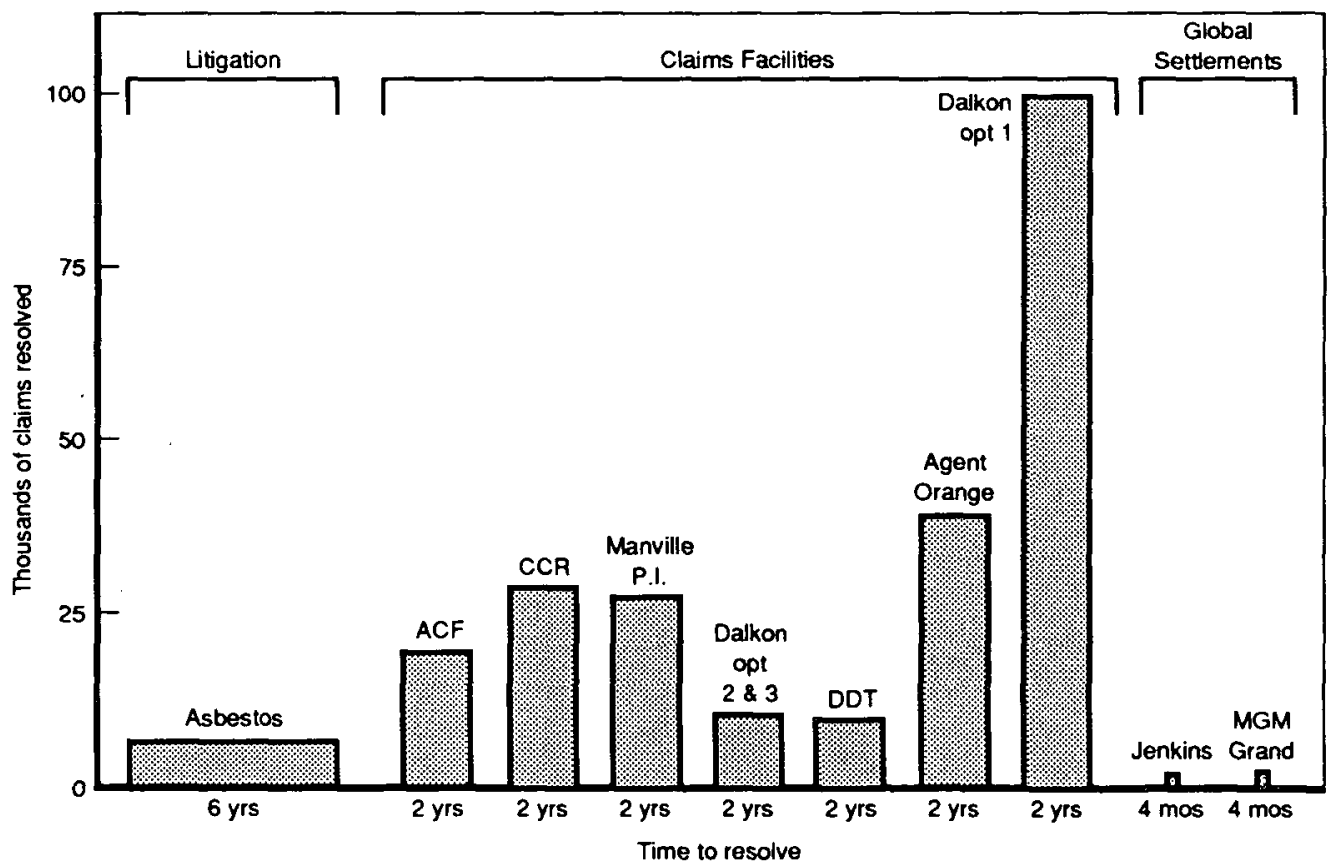


The second timing issue involves the operating delays within a facility as it processes and makes payments on claims. The litigation posture that a facility takes with its distribution process makes a considerable difference in reducing this delay. Figure 11 shows the number of claims resolved by the claims facilities, generally for a two year period. Option 1 of the Dalkon Shield Trust resolved a surprising number of claims, approximately 90,000 in the two years since the option was offered. The administratively simple Agent Orange process was also able to resolve a large number of claims, close to 40,000 within its first two years.

With their more litigious distribution processes, the three asbestos claims facilities processed a lower number of claims. Nevertheless, each facility was far faster than ordinary litigation. The volume during two years of operation for each facility was three to four times the total number of claims resolved during six years of asbestos litigation. ${ }^{46}$

The speed of nonlitigious claims processing is demonstrated even more clearly by Figure 12, which shows the percentage of each facility's claims that have been resolved within two years.

46. The data for each facility were obtained from the following sources. Agent Orange: Report of the Special Master on the Distribution of the Agent Orange Settlement Fund, Second Annual Report 5 (September 27, 1990). Dalkon Shield: 9 Claims Resolution Report: A Newsletter of the Dalkon Shield Claimants Trust (March 1991); Fitzpatrick, 53 L \& Contemp Probs 13 (cited in note 1). Manville: Documents presented at the hearing on the motion to become a limited fund, see note 17 and accompanying text. Asbestos litigation: Kakalik \& Pace, Costs and Compensation Paid in Tort Litigation at xviii (cited in note 35). Olin: Personal communication by Judy Bridgers, April 1991. 
FIGURE 12

Percent of Claims Resolved by Time to Resolve

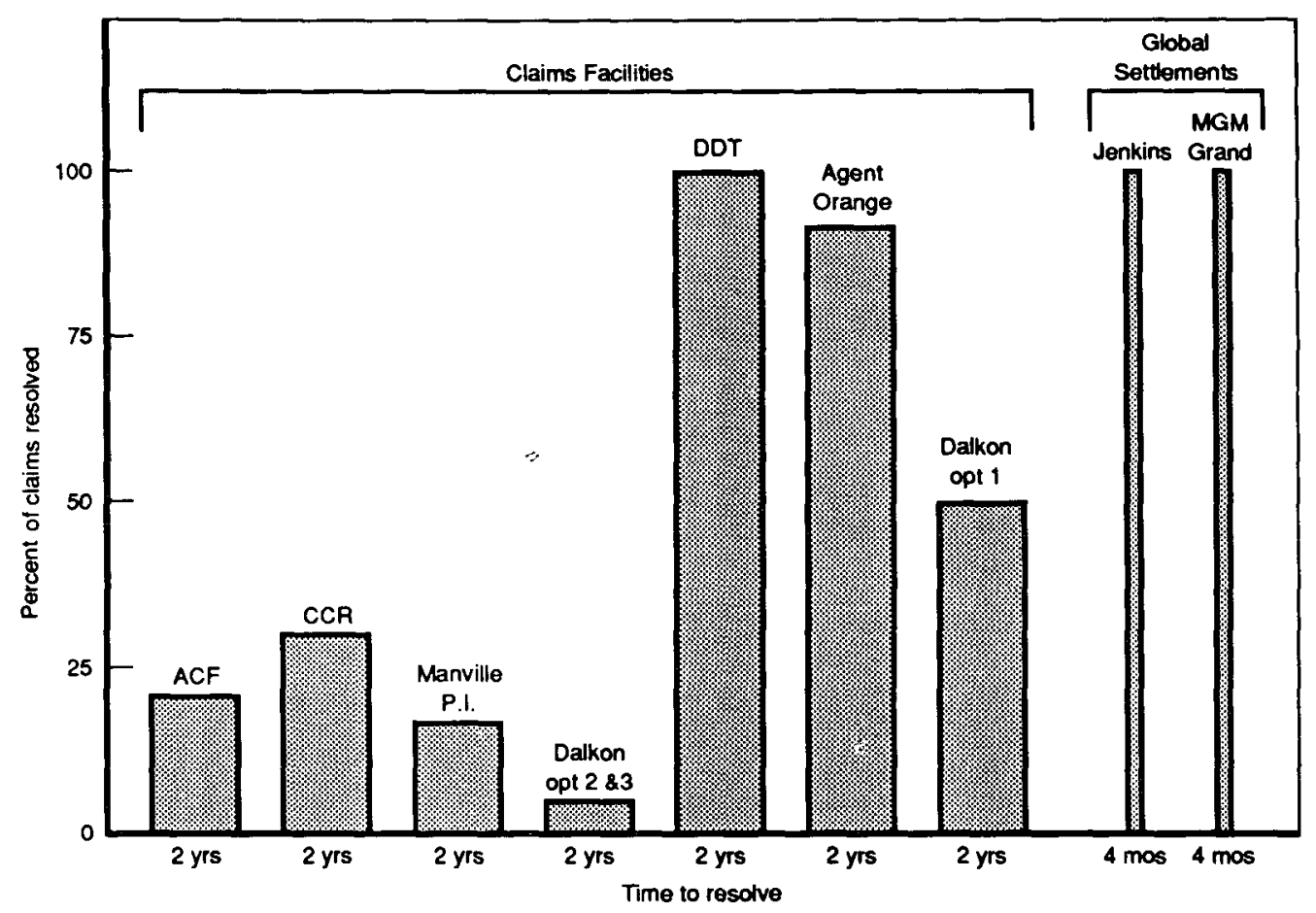

The nonlitigious Option 1 resolved half of the claims pending against the Dalkon Shield Trust. Other facilities using nonlitigious processes were able to resolve almost all pending claims. Thus, a nonlitigious posture clearly saves time, even if it is still unclear how much money it saves.

\section{IV}

\section{Conclusion}

Each of the claims facilities examined in this symposium have been operating for at least two years. Nevertheless, it still is too early to tell how effective such facilities can be in the most troublesome cases involving large numbers of closely contested cases.

Claims facilities seem productive in the most contentious of situations, for example, the asbestos defendants' formation of the Center for Claims Resolution. The coordinated litigation defense of the CCR reduces defendants' expenses and fosters cooperative rather than fractious relationships among defendants. It is important to note, though, that this value is primarily one of strategic advantage to one side of this litigation. While the CCR might provide some efficiencies to plaintiffs who can deal with one entity representing multiple defendants, unlike the other facilities examined in this symposium, it is not designed as a means to provide general distributional efficiencies. 
Claims facilities are also successful in the least contentious situations. Facilities have provided timely compensation for the Agent Orange and DDT claims, where modest money is given to claimants who have legally questionable claims. These are the easiest situations. Compensation is so modest that lawyers have not become involved in pressing claims before the facilities and claimants have little incentive to fight for the last dollar. As with the Dalkon Shield Option 1, these facilities have simply had to disburse moneys without needing to adjust the value of claims.

The success of claims facilities is more clouded where their objectives are most ambitious, that is, where the facility has been substituted for litigation of great stakes to claimants. The experience of the Manville Personal Injury Settlement Trust demonstrates that such facilities must be protected from costly litigation. The original Manville bankruptcy plan scrupulously preserved claimants' rights to trial with disastrous results to the facility's objectives. Recognizing the consequences of unlimited access to trial, the Trust and plaintiffs' lawyers crafted a reorganized plan for the Manville Trust that should effectively eliminate further trials. However, in eliminating trials, the reorganized plan removed the most significant check on the actions of the Trust. To provide such a check, the reorganized plan now requires that the plaintiffs' bar concur in significant future policy decisions by the Trust.

The Dalkon Shield Trust has taken quite an opposite position. That Trust not only refuses to consult with or explain its policy positions to the plaintiffs' bar, but it also has announced that it will not negotiate the value of individual claims. These positions invite claimants to pursue litigation, which could greatly increase the Trust's expenses.

As they continue to operate, the Dalkon Shield and the Manville Personal Injury Settlement Trusts will have to resolve problems in their working relationships with the plaintiffs' bar. To avoid onerous litigation expenses, the Dalkon Shield Trust will likely need to modify policies for evaluating some claims. The Trust's responsiveness at this level need not and should not cause it to relax the control that the Trust has been able to maintain over the processing of individual cases. On the other hand, while the Manville Trust is collaborating with the plaintiffs' bar in setting overall policy, it must assert control over the distribution process, forcing the plaintiffs' lawyers to provide the information necessary to evaluate claims on the Trust's time table. The relationships between the plaintiffs' bar and claims facility are difficult and complex, but the relationships are also critical to the success of those facilities.

The experiences of these claims facilities are important because they will be followed by others as mass litigation continues and as courts and other parties look to make such litigation more efficient. In asbestos litigation alone, eleven defendants have filed for bankruptcy. ${ }^{47}$ Each of these

47. Report of the Judicial Conference Ad Hoc Committee on Asbestos Litigation 14 (March $1991)$. 
bankruptcies may result in a new facility. Indeed, this development suggests new issues that will have to be faced in the future, such as how to combine independent facilities or at least coordinate their operations so that litigation is simplified rather than complicated. In short, claims facilities present a complex array of legal issues, litigation strategies, and administrative difficulties that affect many parties with varying interests. The novel problems facing these facilities will be resolved most successfully if parties have the flexibility to let the facilities evolve and are willing to cooperate to achieve sensible solutions. 